\author{
Volume 6, Issue 4, 653 - 667.
}

ISSN: 2469-9632

https://www.ijem.com/

\title{
Promoting Pre-Service Teachers' Reading Attitudes through Literature Circles: A Mixed Methods Design*
}

\author{
Birsen Dogan \\ Pamukkale University, TURKEY \\ Kasim Yildirim \\ Mugla Sitki Kocman University, Pamukkale University, TURKEY \\ Hulya Cermik* \\ TURKEY
}

Seyit Ates

Gazi University, TURKEY

Received: June 13, 2020 - Revised: September 17, 2020 • Accepted: October 10, 2020

\begin{abstract}
This study explores the impact extended participation in literature circles had on the reading attitudes of university-age preservice teachers following their involvement in literature circles for one academic year, as part of their training. The participants of the study consisted of 21 pre-service teachers with a low or moderate level of reading habits and reading attitudes. The research was conducted through a mixed methods approach. Although both quantitative and qualitative data were collected in the study, particular emphasis was given to the data collected from the qualitative part (quan+QUAL). In line with the quantitative data, it was concluded in the study that extended involvement in the literature circles had a positive effect on the reading attitudes of the pre-service teachers. The qualitative data, which was obtained through interviews, revealed four themes. The themes emerged as love and desire for reading, benefits of reading, importance of reading and reading habits as a result of the analysis. The results obtained from the research are important in terms of contributing to the improvement of pre-service teachers who will play important roles in Turkey's becoming a literate society.
\end{abstract}

Keywords: Pre-service teacher education, instructional practices, mixed methods, literature circles, reading attitudes.

To cite this article: Dogan, B., Yildirim, K., Cermik, H., \& Ates, S. (2020). Promoting pre-service teachers' reading attitudes through literature circles: A mixed methods design. International Journal of Educational Methodology, 6(4), 653-667. https://doi.org/10.12973/ijem.6.4.653

\section{Introduction}

Increasing literacy standards has been a key issue for many countries in terms of their education policies, and teachers have stood out as critical figures of any initiative to improve this situation. The notion that 'one cannot give what one does not have' is reflected in the concept of the Peter Effect in the international literature (Applegate \& Applegate, 2004, p. 561). Applegate and Applegate (2004) clarified that according to the Peter Effect, teachers' lack of reading experience and reading pleasure will create a similar effect in their students, namely the reluctance to read. The students whose teachers read a lot also tend to read (Von Sprecken \& Krashen, 1998). Therefore, it can be suggested that when reading is performed intentionally and with pleasure by teachers who function as role models, students are also likely to perform the act of reading willingly and fondly. Binks-Cantrell et al. (2012) examined the validity of the Peter Effect in teacher preparation education processes and presented evidence that found similarities between teacher educators and preservice teachers in terms of performance. In this sense, it is considered as essential that teachers who desire to develop their students' reading skills and foster a lifelong reading pleasure and reading habit should themselves have these attributes.

Considering the importance of teachers as role models, this study aims to support pre-service teachers to become individuals who take pleasure in reading and love reading through literature circles education. In line with this purpose, it is planned that pre-service teachers will be trained by participating in literature circles during one academic year. Therefore, in the section that follows, details of the literacy education practices of teachers, as well as the literature circles practices that form the basis of the study will be reviewed.

\section{Literacy Education Practices}

In a study by Morrison et al. (1998) a significant and linear relationship was found between whether teachers personally read or not and whether they use literacy education practices in their classes. The practices such as reading a short story in

\footnotetext{
${ }^{*}$ This research was supported by TUBITAK under the Grant 1001 (Project No: 117K108)

** Corresponding author:

Hulya Cermik, Pamukkale University, Faculty of Education, Primary Teaching Department, Denizli, Turkey. $\bowtie$ hcermek@pamukkale.edu.tr
} 
class, introducing new books to students in the class, recommending specific book titles to the class, and reading from a children's novel to the class can be given as examples of the literacy teaching practices mentioned in the study. In the study, it was stated that teachers who use the recommended literacy teaching practices more frequently than others have more positive views about books and reading.

Pressley et al. (1996) reported that teachers who are active in literacy education commonly employ practices related to reading in their classrooms, read to their students almost every day and tell stories once a week. It was revealed that teachers who regard themselves as literacy role models for their students can intentionally exhibit literacy behaviors for the benefit of students (Morrison et al., 1998). Accordingly, it is of critical importance for teachers to devote time to reading, to be engaged in individual readings throughout their lives, and to share books with their students in various ways. No matter where they are -at home, on vacation, etc., in any setting- it is emphasized that teachers need to read (Morrison et al., 1998; Morrow, 1990). Brooks (2007) maintained that students are more likely to be successful, enthusiastic and engaged literates when they study with such teachers. Also, in the studies investigating the relationship between teachers' personal reading habits and their teaching practices, it was determined that teachers who value reading most tend to share their personal reading, and those who have more knowledge about children's literature use better literacy techniques (Burgess et al., 2011; McKool \& Gespass, 2009).

Considering the instructional practices that can be evaluated as factors affecting the attitudes of learners, researchers argued that reading approaches based on dialogues and interaction such as asking questions, explaining, and elaborating that both involve readers in the text and allow them to be active yield more effective results (Protzko et al., 2013; Trivette \& Dunst, 2007). In this regard, literature circles (Daniels, 2002) which are considered to have effects on developing positive attitudes towards reading thanks to their structure that includes these above-mentioned approaches, stand out in the literature.

\section{Literature Circles}

Literature circles is a practice in which students who choose to read the same stories, poems, articles or books gather together to form small groups and discuss and share what is read in these groups (Daniels, 2002). Literature circles are quite different from traditional reading formats. In traditional reading classes, the teacher leads the whole class in discussion, and the students answer the teacher's questions. Usually as time limitations do not allow for lengthy discussions, not every student can participate in the discussions. Considering the fact that some students may be afraid of asking questions or expressing their opinions in front of the class, their opinions or thoughts are not heard at all (Sowder, 1993).

Literature circles include allowing social interaction for students around a common text. According to Brabham and Villaume (2000), literature circles enable students to ask their own questions, make comments, and to both lead and develop the discussion. They also create an atmosphere that will allow students and teachers to reach more complex thinking, language and literacy levels, and enable them to use all of their reading skills and strategies.

Another fundamental feature of literature circles is that students can make their own choices (Sandmann \& Gruhler, 2007). Likewise, Seitz (2010) marked that students' attitudes towards reading can also be improved during their literacy education, and that it is of great importance to provide students with choices in developing a positive attitude towards reading and increasing interest. The choice referred to is about the selection of the book to be read by the students and the roles to be taken in the literature circles. Powell et al. (2006) asserted that these choices encourage students to set goals and take responsibility for their own literacy development. Considering that literacy is a set of skills that can be acquired through the combination of learning, social interaction and gains (Larson \& Marsh, 2005), it can be said that students' having the opportunity to present/share what they read in various environments/contexts will make them more willing to read. In this regard, Almasi (1995) suggested that students who talk about what they have read are more likely to participate in reading.

Practices such as literature circles not only offer students the opportunity to share what they have learned, but also help them to interact while reading through discussions. In recent years, there have been long-term literature circles studies conducted focusing on the analysis of the discourse produced in post-reading group discussions (Shelton-Strong, 2019). Students are given roles to ensure student interaction in small group discussions (Daniels, 2002; Straits \& Nichols, 2006) and in-depth discussions are carried out through these roles.

\section{Roles in Literature Circles}

The roles assumed in literature circles are divided into two groups as basic and optional roles. Basic roles include questioner, connector, literary luminary, and illustrator (Daniel, 2002). The questioner is responsible for preparing questions in a way to enable discussion in the group (Shelton-Strong, 2019; Tracey \& Morrow, 2006). Connector tries to establish connections with what he reads and with his own life, school life or another life around him or make connections with similarities or problems at different times and places (Marchiando, 2013; Shelton-Strong, 2019). The literary luminary is charged with finding something interesting, effective, funny, surprising or important in the book and sharing it with other friends and the illustrator draws a picture of the part he has read (Daniel, 2002). 
Optional roles include the roles such as travel tracer, summarizer, word wizard, and predictor (Daniel, 2002). The travel tracer tracks the location of events and how the places of events change in a book in which characters move a lot or scenes change frequently (Daniel, 2002). The summarizer is responsible for summarizing what he has read (Daniel, 2002; Shelton-Strong, 2019). The word wizard is in charge of searching for important words or concepts that are not clear in terms of meaning while reading (Daniel, 2002). Together with each new literature circle cycle the roles change and rotate. In this way, students have different focuses in each reading and discussion, and their reading awareness increases thanks to having different reasons for reading (Shelton-Strong, 2012).

In this practice, students apply reading/comprehension strategies such as questioning, making connection, inferring, summarizing, and evaluating (Goudvis \& Harvey, 2000) and so they can think more deeply (Bowers-Campbell, 2011; Lloyd, 2004).

\section{Theories Underlying Literature Circles}

Literature circles are theoretically based on Vygotsky's (1978) socio-cultural theory and Rosenblatt's (1978; 2004) readerresponse theory. In addition, literature circles are a part of the wider collaborative learning movement (Daniel, 2002).

Vygotsky's views (1978) form a strong theoretical framework for literature circles. Vygotsky's zone of proximal development provides the basis of literature circles. The zone of proximal development refers to the distance between the child's independent problem solving level and the potential development level under adult guidance or in collaboration with more skilled peers (Vygotsky, 1978). According to this theory, learning takes place when an interaction occurs between individuals. It can be said that this interaction occurs in literature circles when group members perform discussions with role sheets. An example of this can be illustrated by each member assuming a role and sharing responsibilities in the groups to promote collaborative learning.

Another theoretical framework for literature circles is based on Rosenblatt's (1978) views regarding reader-response theory. Rosenblatt (1978) used the concept of transaction to express the relationship between text and reader. This concept is considered to bring into the process a series of networks that include the reader's past experiences, and it is suggested that this network is not only about life but also includes experiences about literature. According to Rosenblatt (1978), who believed that the state of the reader may change in the process, the reader reads for efferent or aesthetic purposes. While the purpose of efferent reading is on obtaining and retrieving information, in aesthetic reading, the reading experience itself and the reader's interaction with the text are important. Based on the literature, Clarke and Holwadel (2007) explained how educators find it necessary to provide opportunities for students to bring in their own interpretation of the reading, contrary to the traditional approach in which the teacher gives meaning to the text. The process of literature circles based on life experiences combines both the reader-response theory developed by Rosenblatt (1978; 2004), the socio-cultural theories developed by Vygostsky (1978) and the basic principles of collaborative learning.

\section{The Study}

According to Applegate and Applegate (2004), it cannot be assumed that even the most successful pre-service teachers in the teacher preparation programs of faculties are enthusiastic/willing readers, and it was reported that many pre-service teachers who do not show this desire have begun their profession. However, they also noted that with well-planned instructional experiences, it is possible to change their views on reading, and it is never too late for this. It has been observed in the literature that many programs implemented have achieved a remarkable level of success in increasing teachers' and pre-service teachers' interest in reading (Bromley et al., 2014; Burbank et al., 2010; Flood \& Lapp, 1994).

The present study was centered on training, and it aimed to determine whether pre-service teachers' attitudes towards reading would change with the practices to be carried out during the teacher preparation process. Based on the literature presented, the present study aims to answer the following research questions:

Q1. Can extended involvement in literature circles show a statistically significant effect on pre-service teachers' attitudes towards reading?

Q2. What extent did the experiences of the pre-service teachers with literature circles transform their attitudes towards reading?

\section{Method}

\section{Research Design}

This study used a convergent mixed methods design to explore the effect of literature circles on the reading attitudes of pre-service teachers, and to reveal how the experiences of pre-service teachers in these affected on their reading attitudes (Creswell \& Plano Clark, 2018). Although both quantitative and qualitative data were collected in the study, emphasis was given to the data gathered from the qualitative part (quan+QUAL). The quantitative stage of the study was conducted as a one-group pretest-posttest design, and the effect of extended participation in literature circles on the reading attitudes of the pre-service teachers was examined. The qualitative phase of the study was carried out as a case study. A case study is a research method that can be used by researchers when searching for an answer to a descriptive or interpretive question 
(Gay et al., 2009). Semi-structured interviews were conducted with pre-service teachers and their opinions about how the literature circles reflected on their reading attitudes were obtained. Through the interviews conducted, an attempt was made to examine in depth how the literature circles affected the pre-service teachers' reading attitudes. The following steps were followed in the convergent mixed methods design used in this research (see Figure 1).

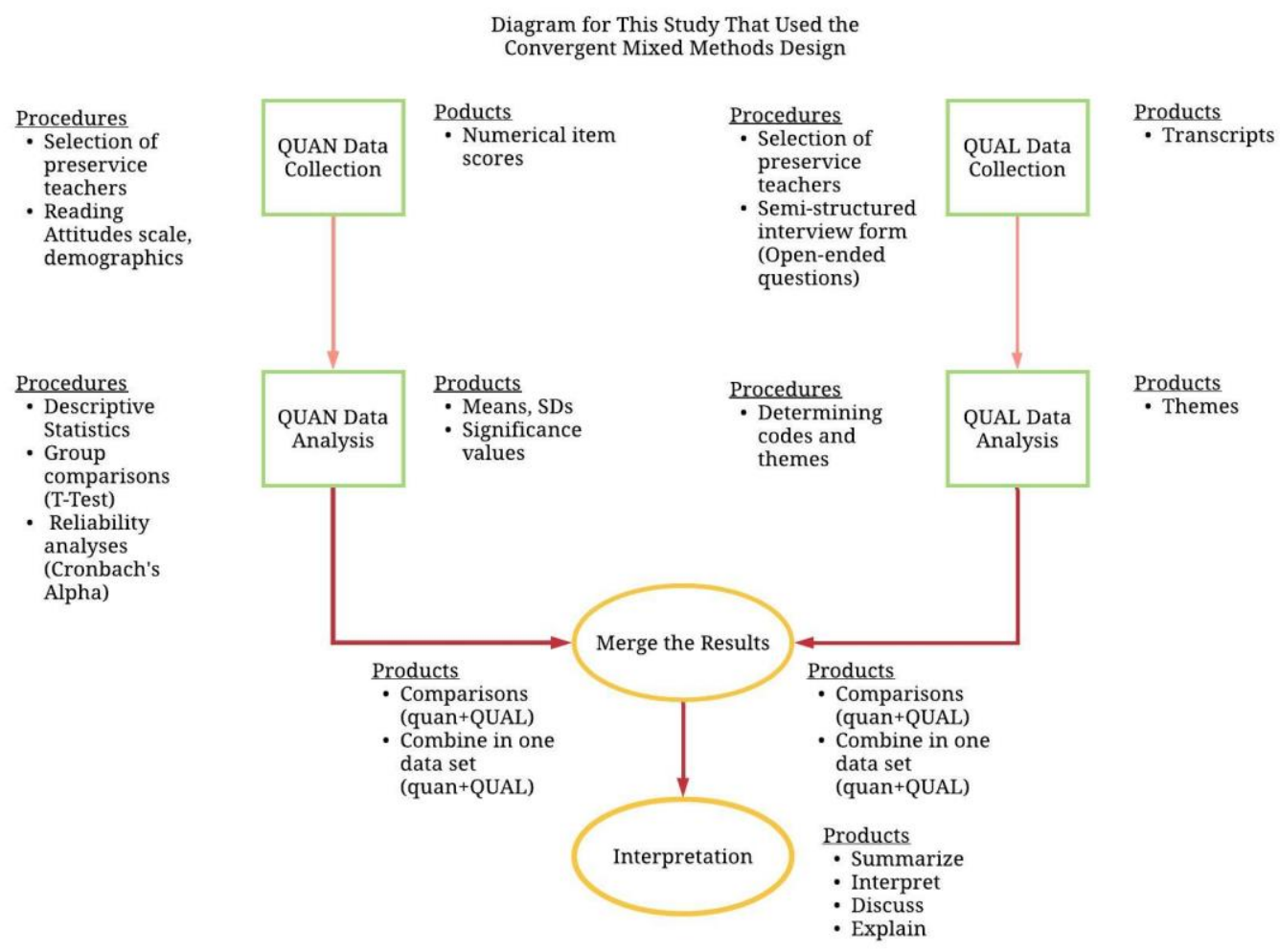

Figure 1. The convergent mixed methods design phases of the research

\section{Participants}

It was decided that the participants of the study should be selected among the pre-service teachers who had low or moderate reading habits and reading attitudes. To that end, the reading habits and reading attitudes of the $3^{\text {rd }}$ year students (85 students) studying in the Department of Primary Education at the Faculty of Education of a state university were selected. The Reading Habits Determination Questionnaire and Reading Attitude Scale (Dogan \& Cermik, 2016) were used for this purpose.

In this study, which is a one-group pretest-posttest design study, the pre-service teachers who showed similar features as a result of the pre-study analyses (pretests and demographic characteristics) were selected for literature circles by taking into account the factors that could threaten the validity and reliability of this study (Appendix A). In terms of internal validity, threats related to students in the experimental and control groups and their experiences were time, change, regression, sample selection, dropouts, and interactions in the selected sample. In this study, since the activities were carried out within the planned time, the time variable was taken under control, as well as the issues of change, regression and interactions in the selected sample since volunteer students with similar characteristics were selected. In addition, since there was no change in the tests and scales used in the study and as standardized tests were used, the factors threatening internal validity that may arise during experimental studies were eliminated (Creswell, 2003, 2005; Salkind, 2000).

Subsequently, a total of 24 pre-service teachers were selected to participate in literature circles activities among the preservice teachers who were generally poor or moderate in reading habits and reading attitudes. Three of these participants had to leave the study for different reasons. As results, a total of 21 pre-service teachers constituted the participants of the study. 15 of these 21 participants were females, and 6 were males and their mean age was 20.09. A verbal consent of the participants was obtained. The participants were assured that the data to be obtained from the interviews would be used for scientific purposes only, and would not be shared with any institution or organization, and a confidentiality/nondisclosure agreement was signed with them. The reading habit and reading attitude scores of the pre-service teachers are presented in Appendix A. 


\section{Measurement Tools}

Quantitative and qualitative data collection tools were used in the study. The Reading Attitude Scale developed by Dogan and Cermik (2016) was used as the quantitative data collection tool. The scale is a five-point Likert-type scale consisting of 36 items, 18 of which are positive and 16 of which are negative. The scale consists of four factors. These factors are: a love of reading books, the benefits of reading, reluctance and stress in reading books, and problems and obstacles in reading books. The Cronbach's Alpha internal consistency coefficient for the whole scale is .95. The Cronbach's Alpha internal consistency coefficients of the sub-dimensions of the scale are respectively .95 for the first sub-dimension, love of reading books, .92 for the second sub-dimension benefits of reading books, .87 for the third sub-dimension reluctance and stress in reading books, .84 for the fourth sub-dimension problems and obstacles in reading books. In this mixed-methods study, which included a total of 21 participants, the internal consistency coefficient (Cronbach's Alpha) for the whole Reading Attitude Scale was determined as .89. The Cronbach's Alpha internal consistency coefficients of the sub-dimensions of the scale are respectively .85 for the first sub-dimension love of reading books, .94 for the second sub-dimension the benefits of reading books, .88 for the third sub-dimension reluctance and stress in reading books, and .64 for the fourth subdimension problems and obstacles in reading books.

A semi-structured interview form was used as a qualitative data collection tool. This form was prepared by the researchers in order to conduct the interviews in accordance with the pre-prepared interview protocol, and contribute to more systematic and comparable information presentation. This form consisted of open-ended and other related probing questions aiming to reveal how the literature circles experiences of pre-service teachers affected their reading attitudes. These questions were (a) How did literature circles change your reading habits? and (b) Are your experiences in literature circles changing your reading attitudes, and if so, how? This form was used during the one-on-one interviews with each participant four times during the research process.

\section{Procedure}

The implementation process in the research was conducted during one academic year. This process was carried out in the Turkish language. The participants read books by Turkish authors. The reason why these books written by living authors were chosen is the desire to meet with the authors. In this context, upon an author's acceptance of the invitation, students came together with the author and had discussions related to the book. During the implementation process, 18 books were read with 21 participants. First, a reviewer was asked to prepare a reading list of living Turkish authors in the book determination stage. Since one of the activities designed in literature circles was "meeting with the authors", it was aimed that the reading list consists of the books of living authors. This list consisted of a total of 50 books. The participants selected 18 books from the list to read two books per month for a 9-month study. The names of the books read, the names of the authors and reading order are given in Appendix B.

As a quantitative data collection method, the Reading Attitude Scale was used as a pre-test at the beginning of the experimental study. The implementation process consisted of 18 literature circles, which were carried out every two weeks in a nine-month period covering approximately one academic year. Literature circles consisted of five members and these members changed every two weeks. One book was read in each literature circle. A circle took a period of two weeks. During this period, two meetings were held regularly regarding that circle. The first meeting covered the parts that were read up to the half of the book. The second meeting was held at the end of the book. In both meetings, responsibilities regarding roles were fulfilled. A series of activities were conducted in each of the literature circles. These activities were forming groups, sharing roles, fulfilling the responsibilities required by roles, discussions, assessments and finally presentation of a project about the book respectively. The presented projects included different activities like drama, poster preparation, book cover design, shooting short films, attending book fairs, organizing forums on the internet, meeting with the author of the book and evaluating the book.

Interviews were used as the qualitative data collection method. A total of four one-on-one interviews were conducted with each of the participants. The interviews were conducted through a semi-structured interview form and data were recorded with a voice recorder. The first interview was conducted after the completion of the literature circle of the first book. The other three interviews were conducted on average three-month intervals. All of the interviews were conducted in accordance with a pre-determined plan of appropriate times for the participants. All interviews were audio-recorded. As a quantitative data collection method, the Reading Attitude Scale was used as a post-test at the end of the experimental study.

\section{Data Analysis}

Descriptive statistical techniques were used in the analysis of the quantitative data obtained from the research. The Shapiro-Wilk test was applied on the reading attitude scores of the students in the study group to see if the data showed normal distribution. In addition, paired $t$-test was used to analyze the reading attitudes of the pre-service teachers.

After all the interviews conducted with the participants, the interviews were transcribed. In this study carried out by four researchers, first, two of the authors independently created a code list to reveal the opinions expressed by the participants and they identified the sub-themes and main themes. Afterward, these authors came together and worked on the sub- 
themes and main themes until they agreed, and a form was prepared in this way. This form was presented to another author of the research team. The author once again coded the expressed by the participants to this form. After this stage, reliability of the research was calculated using this formula: Reliability = Consensus / (Consensus + Disagreement). The consensus was achieved in 112 of the total 124 codes. However, all four researchers once again entered the review process for assignment differences. As a result of this process consensus was achieved in 119 of the 124 codes in total. As a result of the calculation, it was observed that reliability was achieved with $96 \%$ compliance. In the literature, values of $70 \%$ and above are considered sufficient (Miles \& Huberman, 1994). Also, the continuous discussion of the data, and the continuous control of the data by the researchers strengthened the validity (Sarantakos, 2005).

In this research, the findings of all four interviews were converted into tables. In addition, the experiences that create themes were presented through direct quotations to the readers in italics in order to provide a striking view of the participants' emotions, thoughts and experiences. The participant code, gender information and the number of interviews were indicated in parenthesis while presenting views. For instance, the statements expressed by a woman with participant code 11 in her third interview were presented in parenthesis as follows: 11, F, 3.

\section{Findings}

\section{Findings on the effects of literature circles on pre-service teachers' reading attitudes}

In order to answer the first question of the study, first, descriptive statistics of pre-test and post-test scores of the participants' responses to the items in all four sub-dimensions and the reading scale were determined and are presented in Table 1.

Table 1. Descriptive Statistics on the Whole Scale and Factors of the Reading Attitudes Scale

\begin{tabular}{lcclccl}
\hline \multirow{2}{*}{ Sub-dimensions } & \multicolumn{4}{c}{ Pre-test } & \multicolumn{2}{c}{ Post-test } \\
\cline { 2 - 7 } & $\boldsymbol{M}$ & $\boldsymbol{S D}$ & $\begin{array}{l}\text { Level of } \\
\text { Involvement }\end{array}$ & $\boldsymbol{M}$ & $\boldsymbol{S D}$ & $\begin{array}{l}\text { Level of } \\
\text { Involvement }\end{array}$ \\
\hline Love of reading books & 2.47 & 0.64 & Slightly Agree & 4.02 & 0.60 & Strongly Agree \\
The benefits of reading & 3.30 & 1.02 & Mostly Agree & 4.78 & 0.24 & Completely Agree \\
$\begin{array}{l}\text { Reluctance and stress in reading } \\
\text { books }\end{array}$ & 2.78 & 0.85 & Mostly Agree & 4.78 & 0.21 & Completely Disagree \\
$\begin{array}{l}\text { Problems and obstacles in } \\
\text { reading books * }\end{array}$ & 2.67 & 0.59 & Mostly Agree & 4.40 & 0.55 & Completely Disagree \\
Whole Scale & 2.77 & 0.51 & Mostly Agree & 4.45 & 0.32 & Completely Agree \\
\hline
\end{tabular}

* Included reverse coded items

When Table 1 is examined, the following results regarding the first factor, love of reading books, are seen. Participants' scores for this factor were found to be slightly agree with 2.47 average in the pre-test, and strongly agree with 4.02 average in the post-test. When the second factor, the benefits of reading was evaluated, participants' scores were found to be mostly agree with the average of 3.30 in the pre-test and completely agree with the average of 4.78 in the post-test. Since all 9 items in the third factor, reluctance and stress in reading books, contain negative expressions, they were coded inversely and the level of participation of the participants was transformed. When the factor was evaluated, participants' scores were found to be mostly agree in the pre-test and completely disagree in the post-test. The fourth factor, problems and obstacles in reading books, is similar to the previous one. Since all 7 items in this dimension contain negative expressions, they were coded inversely and again the level of participation of the participants was transformed. When the factor was evaluated, participants' scores were found to be mostly agree in the pre-test and completely disagree in the post-test.

When the responses of the participants to the whole scale were examined, scores were found to be mostly agree with 2.77 average in the pre-test and completely agree with 4.45 average in the post-test. In order to determine whether the literature circles showed a significant difference on the reading attitudes of the pre-service teachers, firstly, it was examined whether the data obtained showed normal distribution. It was determined that the total attitude difference scores of reading attitude scale showed normal distribution $(\mathrm{S}-\mathrm{W}=.956, p=.435)$. Therefore, parametric statistical techniques were used.

In order to understand whether there was a significant difference between the pre-test and post-test mean scores of the participants' reading attitude, paired $t$-test analysis was run, and the results were presented in Table 2 below.

Table 2. Paired T-Test Results of the Pre-Test and Post-Test Mean Scores of Reading Attitude of Pre-service Teachers

\begin{tabular}{lllllcc}
\hline & $\boldsymbol{N}$ & $\boldsymbol{M}$ & $\boldsymbol{S D}$ & $\mathbf{d f}$ & $\mathbf{p}$ & $\mathbf{t}$ \\
\hline Pre-test & 21 & 2.77 & 0.51 & 20 & $-12,168$ &, $000^{*}$ \\
Post-test & 21 & 4.45 & 0.32 & & \\
\hline
\end{tabular}


When Table 2 is examined, it is seen that there is a significant difference between the pre-test and post-test scores of participants' reading attitudes $[t(20)=-12.168, p=.000 ; \eta 2=0,615]$. It can be said that this significant difference is in favor of the post-test scores of the participants. Cohen (1988) suggested that $d=0.2$ be considered a 'small', 0.5 represents a 'medium' and 0.8 a 'large' effect size. The effect size of the 0,615 indicated that there is a large effect size and $61.5 \%$ of the total variance can be accounted by pre-test and post-test results.

Findings and comments regarding the extent to which the experiences of literature circles transformed the reading attitudes of the pre-service teachers

The qualitative stage of this research consisted of the opinions of the participants in regards to their experiences in literature circles, and the extent to which these experiences transformed their attitudes towards reading. The data obtained from the interviews were analyzed by content analysis (Miles \& Huberman, 1994). The themes which emerged as a result of the content analysis are presented in Table 3.

Table 3. Opinions of Pre-service Teachers about How They Felt During Implementation Phase of the Literature Circles

\begin{tabular}{|c|c|c|c|c|}
\hline Theme & 1. Interview & 2. Interview & 3. Interview & 4. Interview \\
\hline 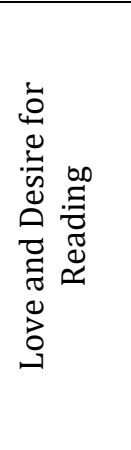 & $\begin{array}{l}\text { The process makes } \\
\text { me love reading } \\
\text { Discussing what we } \\
\text { read is enjoyable } \\
\text { I read willingly }\end{array}$ & $\begin{array}{l}\text { I find reading pleasant } \\
\text { I love reading } \\
\text { It's nice to discuss what } \\
\text { we read with friends } \\
\text { I read willingly }\end{array}$ & $\begin{array}{l}\text { I enjoy reading } \\
\text { The process makes me } \\
\text { love reading } \\
\text { It's a good feeling to read } \\
\text { with a group } \\
\text { I read willingly }\end{array}$ & $\begin{array}{l}\text { I enjoy reading } \\
\text { I love reading } \\
\text { I'm more interested in } \\
\text { books now } \\
\text { I like spending time with } \\
\text { books more than before } \\
\text { now } \\
\text { I exhibit more positive } \\
\text { attitude when I see a } \\
\text { book } \\
\text { I read willingly }\end{array}$ \\
\hline 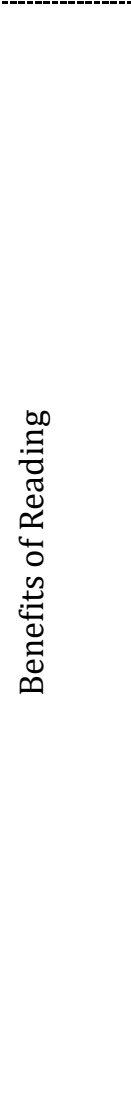 & $\begin{array}{l}\text { I believe it gives } \\
\text { multiple perspectives } \\
\text { I realized it made me } \\
\text { read carefully } \\
\text { I believe that it } \\
\text { ensures effective } \\
\text { reading } \\
\text { I realized it improved } \\
\text { my critical thinking } \\
\text { I'm happy to be active } \\
\text { thanks to it }\end{array}$ & $\begin{array}{l}\text { I noticed the importance of } \\
\text { seeing different } \\
\text { perspectives } \\
\text { Discussion in the group } \\
\text { requires me to read } \\
\text { carefully } \\
\text { Starting to understand the } \\
\text { things that I didn't } \\
\text { understand before makes } \\
\text { me happy } \\
\text { I realized I started to read } \\
\text { in detail } \\
\text { Good to read by visualizing } \\
\text { in my mind } \\
\text { I believe it improves } \\
\text { critical reading } \\
\text { I realized I was able to } \\
\text { make self-assessment }\end{array}$ & $\begin{array}{l}\text { It's good to see that my } \\
\text { point of view is getting } \\
\text { richer } \\
\text { I believe I read effectively } \\
\text { It makes me happy to see } \\
\text { that I interpret what I read } \\
\text { I'm happy to see that I } \\
\text { read in detail } \\
\text { It's good to see that I } \\
\text { started using different } \\
\text { strategies } \\
\text { I'm glad to see it's easier } \\
\text { for me to read than before } \\
\text { I realized it helped me } \\
\text { express my thoughts } \\
\text { I like to see that I evaluate } \\
\text { books better } \\
\text { I like being active } \\
\text { I believe I am a conscious } \\
\text { reader } \\
\text { I realized I have lot to } \\
\text { improve } \\
\text { I notice a positive change } \\
\text { in my pedagogue profile } \\
\text { Being an example reader } \\
\text { to others makes me feel } \\
\text { good }\end{array}$ & $\begin{array}{l}\text { I like reading while } \\
\text { thinking different aspects } \\
\text { I believe I'm practicing } \\
\text { efficient reading } \\
\text { It's good to see that -I'm } \\
\text { reading in a meaningful } \\
\text { way } \\
\text { I believe it develops } \\
\text { higher-order mental } \\
\text { skills } \\
\text { I love being active in the } \\
\text { process } \\
\text { I believe it has a positive } \\
\text { impact on my life } \\
\text { I believe it improves me } \\
\text { both professionally and } \\
\text { personally } \\
\text { I think I'm an effective } \\
\text { reader }\end{array}$ \\
\hline
\end{tabular}


Table 3. Continued

\begin{tabular}{|c|c|c|c|c|}
\hline Theme & 1. Interview & 2. Interview & 3. Interview & 4. Interview \\
\hline 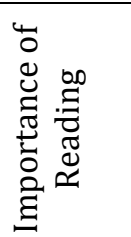 & $\begin{array}{l}\text { I realized I had to } \\
\text { make time to read }\end{array}$ & $\begin{array}{l}\text { I realized that reading is a } \\
\text { need } \\
\text { I feel uneasy if I don't read } \\
\text { Reading is important for } \\
\text { our lives }\end{array}$ & $\begin{array}{l}\text { I feel nervous when I go to } \\
\text { bed without reading } \\
\text { I feel insufficient when I } \\
\text { don't read }\end{array}$ & $\begin{array}{l}\text { I believe reading is a need } \\
\text { I become unhappy when I } \\
\text { couldn't read }\end{array}$ \\
\hline 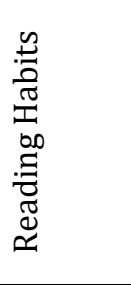 & $\begin{array}{l}\text { It's nice to read } \\
\text { regularly } \\
\text { I like to read all kinds } \\
\text { of books }\end{array}$ & $\begin{array}{l}\text { It's nice to read regularly } \\
\text { I like to know different } \\
\text { types of books } \\
\text { Starting to know different } \\
\text { authors is good }\end{array}$ & $\begin{array}{l}\text { Reading a certain number } \\
\text { of pages every day makes } \\
\text { me comfortable } \\
\text { I gained awareness of } \\
\text { different book types } \\
\text { Good to know different } \\
\text { authors }\end{array}$ & $\begin{array}{l}\text { It's nice to read regularly } \\
\text { I believe it is not right to } \\
\text { read single type of book } \\
\text { I realized that my } \\
\text { perspective about book } \\
\text { types has changed }\end{array}$ \\
\hline
\end{tabular}

When Table 3 is examined, it is seen that four main themes were formed as a result of four interviews including love and desire for reading, benefits of reading, importance of reading and reading habits. It is also seen that the sub-themes differ from interview to interview. The themes and participants' opinions about these themes are discussed in detail in the following headings.

\section{Love and Desire for Reading}

The participants stated that the process of literature circles makes reading more fun and enjoyable and their interest in books is increased. One participant said on this topic, "This process makes me love reading. It gives us the habit of reading books in a fun way, without burden in our daily lives." (13, F, 3). Another participant expressed her opinions as follows, "I wouldn't care reading too much in my life before. When I heard about reading more, I felt like a burden, a duty. I read when I had to. But it started to be more enjoyable when I arranged things" (13, F, 2). Some of the participants stated the reasons why literature circles make reading enjoyable, "We constantly discuss with our friends in literature circles. It's like talking to my friends after watching a movie. It's more enjoyable to read the book like this" (21, M, 1). And, "Sometimes reading is interrupted in literature circles and I liked that. Reading up to a certain page and practicing literature circles is very go od for reinforcing the previous subjects, for stimulating the imagination, and motivating yourselffor the next topic..." (16, F, 1).

Some participants reported that their main problem was to abort reading without finishing the book. However, they shared that they had started to overcome it thanks to literature circles. Regarding to this topic, one participant stated "I was not a reader. I always left the book I had started. I now read the books to the end thanks to the literature circles. I had to have knowledge because we were discussing it. ..." $(8, \mathrm{~F}, 1)$.

\section{Benefits of Reading}

The participants pointed out that literature circles not only increased their love and desire for reading, but also benefitted them personally. Each member has responsibilities in literature circles due to her/his role. Taking different roles in different literature circles is important because it is aimed to develop different aspects of the participants in this way. "I had a positive attitude. We began to pay more attention to the books, because we had a certain task. We started thinking while reading which led us to a better understanding of people, events and the book." $(19, \mathrm{~F}, 1)$ and "...I started to pay more attention when reading. I was trying to read by visualizing it in my mind." (9, F, 2). Participants made these statements expressing the importance of the roles on reading more carefully. Taking different roles in literature circles and performing activities to fulfil them not only turns reading into an makes reading more interactive but also contributes to the development of reading comprehension skills. For example, a participant "I love participating in literature circles. This process made positive reflections on me. It gives us a deeper understanding of the book. I read the book according to the roles. I'm taking notes. I write the sentences that I want to share." (10, F, 3).

One of the participants explained "I have developed many skills such as reading comprehension, interpretation, problem solving and decision making..." $(13, \mathrm{~F}, 4)$, and it is understood from this statement that literature circles can contribute to the development of higher-order mental skills. A participant who plays the role of interrogator recalled, "I compared my questions and groups' questions during the discussion. I started questioning while reading the book..." (10, F, 1), which again emphasizes such benefits.

On the other hand, literature circles are believed to enable students to gain insight into others' perspectives. In this context, "We evaluate books from different perspectives. These are really useful for us. We listen to everyone's comments. We see different perspectives that we didn't see. In this respect, literature circles are very useful and enjoyable." (5, F, 3) and "I try to look multidimensional while reading a book. Instead of reading and passing uniformly I can look critically and it becomes 
an efficient reading. Because I already love reading, literature circles are also enjoyable. This has a positive effect on my attitude towards literature circles." $(5, \mathrm{~F}, 1)$. They mentioned the contribution of the literature circles to seeing different perspectives.

Also "The studies we did during literature circles made me feel different interpretations of the books. But during this time, when I looked at myself about my personal development, I realized that there were more books to read, and I had to read different types." (16, F, 3). "... It is very nice activity that you can improve yourself professionally and personally." (15, M, 1) and "...We have acquired higher-order skills that we can add to ourselves professionally and personally. I think we will pass them on to our students in our professional life in the future. We had a very efficient literature circle. We played an active role and I think we have done good things." (15, M, 4). It is understood from these statements that literature circles contribute to the development of readers.

\section{Importance of Reading}

In order to acquire reading habits, first of all it is important to raise awareness about the importance of reading. The individual must first realize it, apply it, and eventually make it a part of his life, that is, internalize it. The participants seemed to understand this, reporting the following, "It seemed I had no reading habit before. I gained the habit of reading with this activity. I see it differently now. I think reading is a need. Reading desire was vaccinated to our group" (20, M, 2), "My reading habits have increased. I used to read books, but I read occasionally. My need has increased now with this work. I feel that I need reading more. I now read about more areas..." $(6, \mathrm{M}, 4)$. As can be understood from these statements, reading is now felt like a need. On the other hand, some participants stated that they felt uncomfortable, could not sleep and rest when they did not read. "We finished books every two weeks. When I finished a book a week early, I felt empty in second week. I bought a new book and read that book in that week. I feel incomplete at the times when I do not read a book..." (5, F, 2), "I feel restless during the day I don't read." (12, F, 3), “...I can't sleep without reading." (9, F, 3). One participant said, "I wasn't a reader before the literature circle. I didn't think I could spend time on books continuously. I'm starting to feel a gap when I'm not reading a book. I now create the opportunity to read a book even in my most difficult times..." (16, F, 4). These statements suggest that the reading process was internalized.

\section{Reading Habits}

Literature circles include regular meetings to read and discuss a selected book. In the light of the initial data obtained from the participants, it was determined that they did not read books regularly. According to the findings obtained from the interviews, participants explained "Before this project started, our reading attitudes were not regular, and we did not read all the time. Even if we read, it was too short. But after participating in this project, we started to read regularly and consta ntly. I think we have achieved this from my point of view..." (14, M, 4), "Well... now I read more regularly. At least, I can finish one or two books in a month. Previously this did not happen constantly..." (11, F, 2).

The participants stated that their reading habits developed in a positive way as a result of literature circles. "Firstly, we had a nice process and I attended quite willingly. I think I have a habit of reading now." (19, F, 3), "Literature circles have a positive effect on our reading situation. We read little before. We had almost no reading habit before, but we gained this habit with these literature circles. We developed positive attitudes." (20, M, 3). In addition to the process of literature circles, the participants stated that they started reading other times too. "Previously, I was a person who generally did not read books. I find myself reading more books in this process. I also determined the books I should read apart from the process..." (18, F, 3).

In literature circles, students come together for the book they choose and form a group, but they also have the opportunity to meet many different books and genres during the process. Statements demonstrating this are, "My reading habits have changed. We read too many authors. We read a lot of different types of books. This broke my prejudices. Because I was reading same type of books. I can read many different kinds of books right now. I feel interested and curious about the authors I read. My reading attitude has changed like that." (5, F, 4) and "I need to say that I used to read single kind of book before. Murder or crime. But for the first time I've met different types of books in these literature circles. I didn't care until then, but I had to read. So, I saw that I could actually read different types. It also changed the way I look at books. That's literature circles' biggest contribution to me." $(2, \mathrm{~F}, 4)$. From these sample comments, it is seen that the participants acquired the habit of reading, as well as changed their existing reading habits. It is understood that the prejudices that the participants had about different writers and different genres were broken, and they were culturally enriched.

\section{Discussion}

It can be said that several factors of literature circles fueled the desire to read and instilled in these pre-service teachers a love for reading. Some of these factors in the reading process are being engagement, having the freedom to choose which book to read, choosing the necessary roles to play in the circle, sharing what they read, and working on a collaborative basis within the group. Research has shown that instructional practices including approaches based on reading and interaction affect attitudes positively (Hassan, 2018; Protzko et al., 2013; Trivette \& Dunst, 2007; Whittingham, 2014).

In literature circles, students chose the books to read and the roles themselves. This choosing, or autonomy, can be regarded as a positive factor in terms of arousing the desire to read and making them love reading. It can be said that this 
choosing autonomy led to an improvement in the reading attitudes of pre-service teachers of the present study. Seitz (2010), in his study about students' reading attitudes, found that offering choices to the students played a crucial role in developing positive reading attitudes and increased interest. Pre-service teachers find the opportunity to share what they have read with each other in literature circles, and get involved in reading by participating in the discussion through role sheets.

Sandman and Gruhler (2007), in their research, maintained that students were focused on creating meaning within and outside the text through collaborative discussion. It is understood that collaboration promotes the desire to discuss about what is read (Aytan, 2018; Dogan \& Kaya, 2020; Whittingham, 2014). Due to its structure including peer interaction, it is possible to understand these benefits from the perspective of Vygotsky's (1978) socio-cultural theory. It is emphasized that in literature circles, participants can express, in their speech, the emotional responses that contribute to their reading comprehension (King, 2002), opportunities are provided to enable them to participate in discussions that encourage their personal reactions, and their feeling of trust is developed (Sanacore, 2013). Literature circles offer students the opportunity to exchange what they have learned and enables them to share the reading through discussions. Ensuring student involvement in reading is also in line with Rosenblatt's (1978) reader response theory. Oslick's (2011) study also indicated that students are involved in this process by questioning, and that they use questioning expressions to connect with themselves, in particular the books they read, and the world around them. Similarly, Bowers-Campbell (2011) argued that virtual literature circles within the scope of a hybrid approach, enable student-led, deeper, and more inspiring discussions on texts with the help of personal connections and relationships created through small discussions.

It can be inferred that participation in the discussion with role sheets allows for the use of reading comprehension strategies such as questioning, linking, inference, summarizing and evaluating. Supportively, Coccia (2015), based on the qualitative data obtained in his study, concluded that literature circles provided the opportunity for the use of different types of reading comprehension strategies, and that discussion with peers improved reading comprehension. Similarly, there are studies indicating that teachers teach various strategies explicitly, or as models, by using the literature circles in their classes in order to develop their students' reading comprehension (Daniels, 2002; Keene \& Zimmerman, 2007). It is supported by research that literature circles promote a positive reading attitude that increases students' reading proficiency, and through literature circles students become successful in discussing dialogue and content (Bernadowski, 2013; Heineke, 2014; Simpson, 1995).

It can be said that the specific time periods allocated to read a book in the literature circles and the discussions made by the members when this period is over caused the pre-service teachers to read regularly. On the other hand, it was understood that in literature circles, pre-service teachers were affected by others' book choices, and their tendency to read different types of books. Within this context, literature circles broke prejudices of the pre-service teachers, and allowed them to see events from different perspectives. Literature circles promote a continuous and successful interaction with authentic literature as opposed to reading short, skill-oriented texts. As Burke (2016) noted, at the end of literature circles activities, students will be able to think critically, and engage in meaningful dialogue with others.

In this study, it is believed that pre-service teachers' experiences in literature circles are beneficial, and will help them provide new perspectives to be taken into consideration in interacting with students (Monroe-Baillargeon \& Shema, 2010), and therefore literature circles will be an effective learning tool that can be used by teachers (Thein et al., 2011).

\section{Conclusion}

In this study, it was seen that extended participation in literature circles contributed greatly to the pre-service teachers' reading attitudes and helped them to be good readers in this context. Literature circles provided opportunities for the preservice teachers to read comprehensively and to collaborative. With the roles and peer support in group works, preservice teachers were ensured to have in-depth discussions in collaboration. This situation contributed to their own personal enrichment in terms of their reading comprehension development. In addition, it gave them the opportunity to develop their autonomy by allowing them the chance to make selections and decisions freely. They participated in the reading activity with curiosity and enthusiasm as a result of sharing what they read with each other in line with the roles and books they themselves chose. They realized the importance of reading in a learner-centered structure by taking responsibility for their own learning.

\section{Suggestions}

The role of teachers, who are readers and love to read are very important in shaping the future of children. As can be understood from the findings obtained from both quantitative and qualitative data, disseminating the literature circles which seems to have a positive effect on the reading attitudes of pre-service teachers is important. Thus, it can be ensured that pre-service teachers are equipped with sufficient knowledge and skills in the literature circles. This is important for future generations to be literate. It is important to train teachers who can meet the needs of all their students. Based on this fact, it is considered necessary that pre-service teachers participate in literature circles. 


\section{Limitations}

The main limitation of this study is that the practices in the quantitative dimension of the literature circles were carried out as a one-group pre-test post-test design and the practices could not be conducted with the control group. The most important reason for this is that the study period covers one academic year, and the participants to be involved in the control group must read two books each month, and 18 books in total, in a disciplined manner. In the study, 21 people out of 85 volunteer people were selected for the experimental practices. For the control group, students who would voluntarily read two books each month during one academic year could not be reached.

\section{References}

Almasi, J. F. (1995). The nature of fourth graders' sociocognitive conflicts in peer-led and teacher-led discussions of literature. Reading Research Quarterly, 30(3), 314-351.

Aytan, T. (2018). Perceptions of prospective Turkish teachers regarding literature circles. International Journal of Educational Methodology, 4(2), 53-60. https://doi.org/10.12973/ijem.4.2.53

Applegate, A. J., \& Applegate, M. D. (2004). The Peter Effect: Reading habits and attitudes of preservice teachers. The Reading Teacher, 57(6), 554-563.

Bernadowski, C. (2013). Improving the reading attitudes of college students: Using literature circles to learn about content reading. Journal on English Language Teaching, 3(3), 16-24.

Binks-Cantrell, E., Washburn, E. K., Joshi, R. M., \& Hougen, M. (2012). Peter effect in the preparation of reading teachers. Scientific Studies of Reading, 16(6), 526-536.

Bowers-Campbell, J. (2011). Take it out of class: Exploring virtual literature circles. Journal of Adolescent \& Adult Literacy, $54(8), 557-567$.

Brabham, E. G., \& Villaume, S. K. (2000). Questions and answers: Continuing conversations about literature circles. The Reading Teacher, 54(3), 278-280.

Bromley, K., Faughnan, M., Ham, S., Miller, M., Armstrong, T., Crandall, C., Garrison, J., \& Marrone, N. (2014). Literature circles go digital. The Reading Teacher, 68(3), 229-236.

Brooks, G. (2007). Teachers as readers and writers and as teachers of reading and writing. The Journal of Educational Research, 100(3), 177-191.

Burbank, M. D., Kauchak, D., \& Bates, A. J. (2010). Book clubs as professional development opportunities for preservice teacher candidates and practicing teachers: An exploratory study. The New Educator, 6(1), 56-73.

Burgess, S. R., Sargent, S., Smith, M., Hill, N., \& Morrison, S. (2011). Teachers' leisure reading habits and knowledge of children's books: Do they relate to the teaching practices of elementary school teachers? Reading Improvement, 48(2), 88-102.

Burke, B. M. (2016). Developing world language students' proficiency with reader's workshops and extensive reading during literature circles. In A. J. Moeller (Ed.), Fostering connections, empowering communities (pp. 205-229). Robert M. Terry.

Clarke, L. W., \& Holwadel, J. (2007). Help! What is wrong with these literature circles and how can we fix them? The Reading Teacher, 61(1), 20-29.

Creswell, J. W. (2003). Research design: Qualitative, quantitative, and mixed methods approaches. Sage Publications Inc.

Creswell, J. W. (2005). Educational research: Planning, conducting, and evaluating quantitative and qualitative research (2nd ed.). Pearson Education Inc.

Creswell, J. W., \& Plano Clark, V. L. P. (2018). Designing and conducting mixed methods research. Sage Publications Inc.

Coccia, L. (2015). Literature circles and their improvement on comprehension a focus on elementary students [Unpublished master's thesis]. St. John Fisher College.

Cohen, J. (1988). Statistical power analysis for the behavioral sciences. Lawrence Erlbaum Associates.

Daniels, H. (2002). Literature circles voice and choice in book clubs and reading groups. Pembroke Publishers.

Dogan, B., \& Cermik, H. (2016). Kitap okumaya yonelik tutum olcegi: Gecerlik ve guvenirlik calismasi [Attitude scale towards reading: Validity and reliability study]. Education Sciences, 11(3), 168-183.

Dogan, B., \& Kaya-Tosun, D. (2020). An effective method in improving social skills: Literature circles, International Journal of Educational Methodology, 6(1), 199-206. 
Flood, J., \& Lapp, D. (1994). Teacher book clubs: Establishing literature discussion groups for teachers. The Reading Teacher, 47, 574-576.

Gay, L. R., Mills, G. E., \& Airasian, P. (2009). Educational Research: Competencies for analysis and applications (9th ed.). Pearson Education Inc.

Goudvis, A., \& Harvey, S. (2000). Strategies that work: Teaching comprehension to enhance understanding. Stenhouse

Hassan, H.S. (2018). Instructors' attitude on the use of 'literature circles' in teaching literature. Polytechnic Journal, 8(2), 142-158.

Heineke, A. J. (2014). Dialoging about English learners: Preparing teachers through culturally relevant literature circles, Action in Teacher Education, 36(2), 117-140.

Keene, E. O., \& Zimmermann, S. (2007). Mosaic of thought: The power of comprehension strategy instruction. Portsmouth.

King, C. (2002). 'I like group reading because we can share ideas': The role of talk within the literature circle. Reading, $35(1), 32-36$.

Larson, J., \& Marsh, J. (2005). Making literacy real: theories and practices for learning and teaching. Sage Publications.

Lloyd, S. L. (2004). Using comprehension strategies as a springboard for student talk. Journal of Adolescent \& Adult Literacy, 48(2), 114-124.

Marchiando, K. (2013). Creating lifelong readers: Student ownership and peer interaction in literature circles. Illinois Reading Council Journal, 41(3), 13-21.

McKool, S. S., \& Gespass, S. (2009). Does Johnny's reading teacher love to read? How teachers' personal reading habits affect instructional practices. Literacy Research and Instruction, 48(3), 264-276.

Miles, M. B., \& Huberman, A. M. (1994). Qualitative data analysis. Thousand Oaks.

Monroe-Baillargeon, A., \& Shema, A. L. (2010). Time to talk: An urban school's use of literature circles to create a professional learning community. Education and Urban Society, 42(6) 651-673.

Morrison, T. G., Jacobs, J. S., \& Swinyard, W. R. (1998). Do teachers who read personally use recommended literacy practices in their classroom. Literacy Research and Instruction, 38(2), 81-100.

Morrow, L. M. (1990). Preparing the classroom environment to promote literacy during play. Early Childhood Research Quarterly, 5(4), 537-554.

Oslick, M. E. (2011). Inquiry in teacher literature circles. Florida Association of Teacher Educators Journal, 1(11), 44-56.

Powell, R., McIntyre, E., \& Rightmyer, E. (2006). Johnny won't read, and Susie won't either: Reading instruction and student resistance. Journal of Early Childhood Literacy, 6(1), 5-31.

Pressley, M., Rankin, J., \& Yokoi, L. (1996). A survey of instructional practices of primary teachers nominated as effective in promoting literacy. The Elementary School Journal, 96(4), 363-384.

Protzko, J., Aronson, J., \& Blair, C. (2013). How to make a young child smarter. Perspectives on Psychological Science, 8(1), 25-40.

Rosenblatt, L. M. (1978). The reader, the text, the poem: The transactional theory of the literary work. Southern Illinois University Press.

Rosenblatt, L. M. (2004). The transactional theory of reading and writing. In R. B. Ruddell \& N. J. Unrau (Eds.), Theoretical models and processes of reading (pp. 1363-1368). International Reading Association.

Salkind, N. J. (2000). Exploring research. Prentice-Hall, Inc.

Sanacore, J. (2013). "Slow down, you move too fast": Literature circles as reflective practice. The Clearing House, 86(3), 116-120.

Sandmann, A., \& Gruhler, D. (2007). Reading is thinking. International Journal of Learning, 13(10), $105-113$.

Sarantakos, S. (2005). Social Research (3rd ed.). Palgra and Macmillian.

Seitz, L. (2010). Student attitudes toward reading: A case study. Journal of Inquiry and Action in Education, 3(2), 30-44.

Shelton-Strong, S. J. (2012). Literature circles in ELT. ELT Journal, 66(2), 214-223.

Shelton-Strong, S. J. (2019). An analysis of collaborative dialogue in literature circles. In C. Jones (Ed.), Literature, spoken language and speaking skills in second language learning (pp. 176-201). Cambridge University Press.

Simpson, A. (1995). Not the class novel: A different reading program. Journal of Reading, 38(4), 290-294. 
Sowder, W. H. (1993). Fostering discussion in the language-arts classroom. The English Journal, 82(6), 39-42.

Straits, W., \& Nichols, S. (2006). Literature circles for science. Science and Children, 44(3), 52-55.

Thein, A. H., Guise, M., \& Sloan, D. L. (2011). Problematizing literature circles as forums for discussion of multicultural and political texts. Journal of Adolescent \& Adult Literacy, 55(1), 15-24.

Tracey, D., \& Morrow, L. M. (2006). Lenses on reading: An introduction to theories and models. Guilford Press.

Trivette, C. M., \& Dunst, C. J. (2007). Relative effectiveness of dialogic, interactive, and shared reading interventions. Center for Early Literacy Learning Reviews, 1(2), 1-12.

Von Sprecken, D., \& Krashen, S. (1998). Do students read during sustained silent reading? The California Reader, 32(1), 1113.

Vygotsky, L. S. (1978) Mind in society: The development of higher psychological processes. Harvard University Press.

Whittingham, J. (2014). Reading motivation: A study of literature circles. Academic Exchange Quarterly, 18(2), 1096-1453 


\section{Appendix A}

Reading Habits and Average Reading Attitude Scores of Pre-service Teachers

\begin{tabular}{clllc}
\hline No & Number of books read per year & Last reading date & Time for Reading & Attitude Average \\
\hline 1 & Between 1-5 Books & $1-7$ days before & I do not read regularly & Left \\
2 & Between 6-11 Books & $1-7$ days before & I do not read regularly & 2.13 \\
3 & Between 6-11 Books & Other & I do not read regularly & 2.11 \\
4 & Between 6-11 Books & $1-7$ days before & I do not read regularly & 2.77 \\
5 & Between 6-11 Books & $1-7$ days before & $31-60$ minutes & 255 \\
6 & Between 1-5 Books & Other & I do not read regularly & Left \\
7 & Between 1-5 Books & Other & I do not read regularly & 2.55 \\
8 & Between 1-5 Books & Other & I do not read regularly & 2.97 \\
9 & Between 1-5 Books & One year ago regularly & 2.27 \\
10 & Between 1-5 Books & $1-7$ days before & I do not read regularly & 2.83 \\
11 & Between 1-5 Books & $1-7$ days before & I do not read regularly & 3.02 \\
12 & Between 1-5 Books & Other & I do not read regularly & 3.02 \\
13 & Between 1-5 Books & 30 days before & I do not read regularly & 2.02 \\
14 & Between 6-11 Books & $1-7$ days before & I do not read regularly & 2.55 \\
15 & Between 1-5 Books & Other & I do not read regularly & 3.22 \\
16 & Between 6-11 Books & $1-7$ days before & I do not read regularly & 2.3 \\
17 & Between 1-5 Books & $1-7$ days before & I do not read regularly & 4.05 \\
18 & Between 1-5 Books & $1-7$ days before & I do not read regularly & 2.69 \\
19 & Between 1-5 Books & $1-7$ days before & Other & 2.61 \\
20 & Between 1-5 Books & $1-7$ days before & I do not read regularly & 3.66 \\
21 & Between 1-5 Books & More than one year & I do not read regularly & 3.3 \\
22 & Between 1-5 Books & $1-7$ days before & I do not read regularly & Left \\
23 & Between 6-11 Books & $1-7$ days before & 1-30 minutes & 2.72 \\
\hline
\end{tabular}


Appendix B

List of the Books Read during the Literature Circles Implementation

\begin{tabular}{cll}
\hline No & Title of Book & Name of Author \\
\hline 1 & Kac Zil Kaldi Ortmenim [How Many Bells are Left, Teacher] & Filiz Aygunduz \\
2 & Suzan Defter [Suzan the Notebook] & Ayfer Tunc \\
3 & Cinayet Fakultesi [Faculty of Murder] & Pinar Kur \\
4 & Kafamda Bir Tuhaflik [A Strangeness in My Mind] & Orhan Pamuk \\
5 & Sultani Oldurmek [To Kill a Sultan] & Ahmet Umit \\
6 & Bana Sen Soyle [You Tell Me] & Necati Tosuner \\
7 & Civan [Civan] & Muge İplikci \\
8 & Puslu Kitalar Atlasi [The Atlas of Misty Continents] & Ihsan Oktay Anar \\
9 & Ve Bir Pars Huzunle Kaybolur [And a Pars Disappears with Sorrow] & Faruk Duman \\
10 & Ruya Koru [Dream Blind] & Gursel Korat \\
11 & Varolmayanlar [Nonexistents] & Dogu Yucel \\
12 & Barbarin Kahkahasi [Laughter of the Barbarian] & Sema Kaygusuz \\
13 & Akhisar Duserken [Falling of Akhisar] & Mahmut Senol \\
14 & Karanlik Oda [The Dark Room] & Hakan Bicakci \\
15 & Hayati Sevme Hastaligi [Life Love Disease] & Sibel K. Turker \\
16 & Az [The Few] & Hakan Gunday \\
17 & Soluk Bir An [A Faint Moment] & Behcet Celik \\
18 & Bu Yalan Tango [This Unreal Tango] & Selim İleri \\
\hline
\end{tabular}

